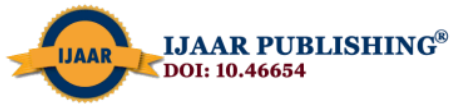

International Journal of Advanced Academic Research (Arts, Humanities and Education) | ISSN: 2488-9849

Vol. 6, Issue 12 (December, 2020) |www.ijaar.org

Journal DOI: 10.46654/ij.24889849

Article DOI: 10.46654/ij.24889849.a61245

\title{
STUDENTS' INDISCIPLINE IN HIGHER EDUCATIONAL INSTITUTIONS OF SOKOTO STATE: THE FORMS, CAUSES AND MANAGEMENT APPROACHES
}

\author{
Sa'adu Isa Bashar ${ }^{1}$ \\ Department of Educational Foundations, \\ Faculty of Education, Sokoto State University, PMB 2134, Sokoto, Nigeria. \\ Phone: +234 (0) 7062250773; \\ Email-mmbashar1984@gmail.com
}

\author{
Mudassir Ibrahim Gatawa ${ }^{2}$, Bello Musa ${ }^{3}$, Nafi'u Abdul'Aziz ${ }^{4}$, Adamu Hassan $^{5}$ \\ Department of Educational Foundations, \\ Faculty of Education, Sokoto State University, Sokoto, Nigeria. \\ Prof. Muhammad Mustapha Jagaba ${ }^{6}$ \\ Department of Adult Education, FEES, UDUS; \\ Department of Educational Foundations, Faculty of Education, \\ Sokoto State University, Sokoto, Nigeria.
}

\begin{abstract}
The purpose of this research was to investigatethe students' indiscipline in tertiary institutions of learning in Sokoto State, Nigeria. Specifically, the study aimed at examining the forms of students' indiscipline, the causes of students' indiscipline and its management approaches in the institutions.The study was a mixed method design combining two forms of data- quantitative and qualitative. The population of the study was 7,614 subjects which comprised of 3,270 academic staff and 4,344 final year students of all the tertiary educational institutions of Sokoto State. On the quantitative phase, the study employed a proportionate stratified random sampling technique in selecting692 sample based on the guidelines of Krejcie and Morgan (1970).Conversely, 12 participants were sampled for the interview based on the saturation rule. A self-developed instrument titled 'Strategies for Managing Students' Disciplinary Problems in Tertiary Educational Institutions Questionnaire (SMSDPTEIQ)' was administered to 692 lecturers and students after which it was validated by experts and its reliability was established at 0.9. The study found that among the forms of students' indiscipline in the institutions were drug abuse, examination malpractice, fighting, and noise making in the classrooms. It was also found that the causes of students' indiscipline in the institutions were lack of parental counseling, mixed nature of the institutions, and ineffectivemanagement strategies. It was also found that the institutions use certain approaches to manage the students' indiscipline, such as setting down policies and regulations, communicating the policies to the school-wide communities, apprehending and detaining the indiscipline students. The study finally recommends among other things that the institutions should seek the support of the parents of the students and the entire community members in dealing with the indiscipline behaviours of the students.
\end{abstract}

Keywords: Indiscipline, Tertiary institutions, Forms, Causes, Managing Approaches. 


\section{Introduction}

Primarily, educational institutions were established to provide knowledge, skills, positive characters and discipline to the teeming students who are mostly youths- the future hopes of the nations (Bashar, 2017). However, by the advent of the $21^{\text {st }}$ century, indiscipline among students of institutions of learning become evident, apparent and increasingly escalating (Ofori, Tordzro, Asamoah, \& Achiaa, 2018). This has raised serious concerns among all stakeholders of education, policy makers, parents and community membersin almost all countries including Nigeria as to why the problem persists? Today, no country exists without the problem of students' indiscipline. That was why different nations strive to find out the root cause and lasting solutions to the problem. Studies in the literature indicated that even the super power countries e.g. the United Kingdom and United States of America, acknowledge the problem of students' indiscipline in their schools. Stones (2013) contended that indiscipline among the American students has been one of the major problems affecting their schools to the extent that teachers chooseto abandon and retire their services from the schools that have serious issues of indiscipline to protect their lives and dignities and consequently deploy to other schools with some level of discipline. Similarly, Mucmahron (2009) reported that in the United Kingdom, more than 2000 students were expelled as principals struggled to deal with their violent and unruly attitudes of the students. Again, Azizi et al, (2009) reported that in the Malaysian schools, students' indiscipline prevails in terms of assaults on teachers from students, verbal abuse, speaking offensive language to teachers, sexual harassment, intimidation of teachers, possession of weapons, possession of illegal drugs, intrusions into the school or classrooms by adults with the intention of confronting teachers among others.

This issue of students' indiscipline does not only exist in Europe and Asia, but is also available in the African nations. Studies in South Africa (Mtsweni, 2008), Ghana (Ofori, et, al. 2018), and Kenya (Karanjal\& Bowen, 2012), showcased that students' indiscipline exists in their educational institutions and thus affects the smoothness of teaching and learning processes. In Nigeria, Nakpodia, (2010) and others reported in different studies the kinds of indiscipline attitudes that manifest among the students of Nigerian institutions of learning including the tertiary,such as the rampant violation of the rules and regulations, cultism, theft, arrogance, drug abuse, absenteeism, truancy, examination malpractices, illicit sex, destruction of school properties, violence in schools and the host of others. Undoubtedly, these problems hinder the effectiveness of the teaching and learning until they are fully addressed.

However, in Sokoto State, Sule, (2014) reported that the tertiary educational institutions in the State were never free from this menace due to apparent manifestations of indiscipline attitudes from the students of the institutions and therefore many parents and guardians worried much with the rate at which their children learn and master the acts of indiscipline.Even though some studies in other parts of the country e. g. Olaitan, et al, (2013), Petersen and Rosser, (2008), Zubaida, (2009), Nakpodia, (2010), and Aneibonam, (2011), indicated some of the indiscipline attitudes of the Nigerian students in the primary, secondary and tertiary institutions, however,much is not known in the literature on the forms, causes, and management approaches of students' indiscipline in the tertiary educational institutions of Sokoto State. This prompted the researchers to undertake the study so as to examine theseissues and to bridge the research and literature gaps.Specifically, this research intends to answer the following research questions: 


\section{i. What are the forms of students' indiscipline in the tertiary educational institutions of Sokoto State? \\ ii. What are the causes of indiscipline among the students of tertiary educational institutions of Sokoto state? \\ iii. What are the Approaches for managing students' indiscipline in the tertiary educational institutions of Sokoto State?}

\section{Literature Review}

\section{- $\quad$ The Concept of Indiscipline}

The concept of students' indiscipline has been understood by Aniebonam (2011) as the untrained minds and characters of students which lead to disobedient to authority. Similarly, Zubaida (2009) perceived the concept of students' indiscipline as the act ofdisrespectingthe school laws and regulations and compromising the established standards of behaviors. In another circumstance, Igwe (2000) defined indiscipline as the socially unapproved pattern of life which the immature students involve themselves to avoid good performance of the roles expected of them in the schools. In addition, students' indiscipline was described as a kind of students behaviour that serve as clearly unethical and compromise the normal standards of societal values and norms (Ofori, et al., 2018).

\section{- Forms of Indiscipline among the Nigerian Students}

Literature indicates that different kinds of indiscipline acts that are noticeable among the students of tertiary institutions in Nigeria include truancy, stealing, fighting, absenteeism, examination malpractice, indecent dressing, sexual harassment, cultism, and corruption. Others include drug abuse, smoking, alcohol consumption, disobedience to teachers and school rules and regulations, dodging from the schools at unauthorized hours, noise making in the classrooms, participation in students' unrest to chatting social media in the presence of the teacher in the class. These acts had been either performed in group or on individual basis by the students. These acts of indiscipline were identified in different studies such as that of Peterson and Rosser (2008), Zubaida (2009), Nakpodia (2010), Aneibonam (2011), Olaitan, (2013), among others. According to these scholars, these various forms of indiscipline cut across students of all levels of educational institutions right from primary to tertiary and these will continue to affect the quest for effective teaching and learning and quality education until they are eventually overcome.

\section{- Causes of students' indiscipline}

Many scholars opined that different factors were responsible for students' indiscipline in schools. These include parental factor, political factor, socio-economic factor, school factor, curriculum factor, and peer group factor.

Accordingto Olaitan et al. (2013) most scholars regard parents as of the greatest importance in creating a conducive teaching and learning atmosphere. It seems that the lack of parental involvement is the major cause of disciplinary problems in secondary schools. From the perspective of Alidzulwi (2000), many parents are not involved in the education of their children, 
causing poor results, high dropout rates, and the absence of discipline in schools. Also, Bowman (2004) believes that parents' failure to teach their children discipline is identified as the greatest contributing factor to disciplinary problems in schools.

According to Rossouw (2003), Olaitan et al. (2013), politics and socio-economic factors are some of the responsible causes of students' indiscipline in schools.According to them, teachers have reported that they are uncertain, confused and afraid of infringing upon learners' rights, and of being accused of misconduct. Saying that the over-emphasis placed on learners' rights may cause a kind of don't-care attitude and lack of regard for the educators' role in the classroom. This may cause some learners not to strive to excel. Instead, they try to influence their classmates negatively to exhibit the same lack of discipline. Thus, children who experience social alienation from others are often misbehaved.

School Environment as a factor. Olaitan et al. (2013) contends that every school manager is committed to ensuring that school provides a safe and orderly environment in which teaching and learning take place each day. Olaitan (2013) posited that safe and supportive school environments depend on students, staff and parents demonstrating mutual respect. This is to say all members of the school community students, staff and parents must know and understand the standards of behaviour which all students are expected to live up to and the consequences if these standards are not met. Every student has the right to a learning environment free from bullying and intimidation and to feel safe and happy at school. They have a right to be treated fairly and with dignity (Terry, 2001). In addition, every community has rules. The school community is no exception. A school makes reasonable rules for the good order of the school and the discipline of students. Schools have the power to enforce these rules by using discipline or punishment.

Curriculumis one of the causes of causes of students' indiscipline in schools (Olaitan, 2013). This is because the relevance of curriculum to the learners' needs influences discipline at school. The author further ascertain that learners engage in several forms of deviant behaviour if the curriculum is not able to offer them opportunities for self-development and a sense of personal worth, and do not address the aims that are promoted by society. Also, learners' resort to taking matters into their own hands if they believe that the curriculum is irrelevant and boring.

Peer Group Influence is one of the responsible causes of students' indiscipline in schools (Olaitan, et al., 2013). The peer group influences what the child values, knows, wears, eats and learns. The extent of this influence however depends on other situational constraints, such as the age and personality of children and the nature of the group (Harris, $2002 \&$ Hartup, 1983). There is no doubt that considerable evidence supports the statement that peer relationships influence the growth of problem behaviour in youth. Expressing further, they buttressed that peer group can demand blind obedience to a group norm, which can result in socially alienated gangs with pathological outlooks.

- Approaches for Managing Students' indiscipline

Management of indiscipline is concerned with the establishment and maintenance of order and the harmonious functioning of a society (Musisi, 2014). According to him dealing with students' indiscipline in institutions of learning is a collaborative responsibility of all the school 
stakeholders that comprised of a school manager, teaching and nonteaching staff of the institution in order to create a discipline and safe learning environment. To deal with the disruptive behaviours of students, Bell (1995) and Dreikur (2015) have suggested the use of certain approaches. They proposed that students be respected by teachers through instilling in them a sense of responsibility, provide teachers with effective training that will enable the students acquire and master problem-solving and negotiation techniques, prevent violence and promote order in schools, detain the indiscipline students, suspend or temporary exclude the indiscipline students, expel the indiscipline students from the school, deprive privilege to the indiscipline students, give them moral punishment to learn how to tender apologies, degradethe indiscipline students from positions whether public or private, share some management responsibilities with the students, blame the erring students, and use reward and punishment when and where necessary.

\section{Materials and Method}

The research employed a mixed method approach of sequential explanatory design which demanded the researchers to triangulate the quantitative and qualitative methods to generate more strong and reliable data that could inform concrete generalization and conclusion (Airat, 2014; Creswell \& Creswell, 2018). The population of the study was 7,614 subjects. This comprised of 3, 270 Academic Staff and 4,344 final year students of all the tertiary educational institutions of Sokoto state. Proportionate stratified random sampling approach was used to select 692 respondents from the population based on the sampling procedures of Krejcie and Morgan (1970). The technique was considered appropriate as it gives the researchers ability to sample each of the institutions based on its peculiar population strength (Creswell \& Creswell, 2018). A self-designed,close-ended questionnaire titled "Strategies for Managing Students' Disciplinary Problems in Tertiary Educational Institutions Questionnaire" (SMSDPITEQ) with a modified four-point Likert's Rating Scale was used to capture the respondents' opinions. Also, an Interview schedule was developed for the interview with 12 academic staff of the institutions. After the validation by experts, and pilot study, the reliability index of the Questionnaire was established at 0.9 through the SPSS Cronbach Alpha.

\section{Results Analysis}

This section analyzed both the survey data and the interview. The survey data was presented in tables of Mean and Standard Deviationbased on respective research questions and then was followed by the interview responses. 692 questionnaires were distributed to both the academic staff and final year students of the tertiary educational institutions of Sokoto State.

However, Six Hundred and Eighty-Seven (687) questionnaires were retrieved from the respondents while Eight (8) were missing. This means there was about $98 \%$ response rate from the respondents and was proved to be adequate for generalizing the information for the study (Amin, 2005).Similarly, 12 academic staff coded from A1 to A12 were interviewed and their responses were transcribed and analyzed. The decision cut-off point for the quantitative result was that any mean score which was equal to or less than 2.00 , was considered as 'disagreement' while any mean score that was equal to or greater than 3.00, was regarded as 'agreement'. The decisions were coded as 'A' for Agree and ' $D$ ' for Disagree. 
Research Question One: what are the forms of students' indiscipline in the tertiary educational institutions of Sokoto State?

Theforms of students' indiscipline in tertiary educational institutions of Sokoto State are shown in table 1 thus:

Table 1: forms of students' indiscipline

\begin{tabular}{lllll}
\hline SN & \multicolumn{1}{c}{ Descriptor items } & N & Mean & SD \\
\hline 1 & There is problem of Drug Abuse among the students & 687 & 3.05 & .481 \\
\hline 2 & $\begin{array}{l}\text { There is problem of Examination malpractice among } \\
\text { the students }\end{array}$ & 687 & 3.42 & .494 \\
\hline 3 & There is problem of fighting among the students & 687 & 2.84 & .526 \\
\hline 4 & $\begin{array}{l}\text { There is problem of noise making in the lecture rooms } \\
\text { by students }\end{array}$ & 687 & 3.18 & .581 \\
\hline 5 & There is problem of stealing among the students & 687 & 2.72 & .449 \\
\hline 6 & $\begin{array}{l}\text { There is problem of indecent dressing among the } \\
\text { students }\end{array}$ & 687 & 3.24 & .603 \\
\hline 7 & $\begin{array}{l}\text { There is problem of adultery and fornication among } \\
\text { the students }\end{array}$ & 687 & 2.86 & .345 \\
\hline 8 & $\begin{array}{l}\text { There is illegal possession of weapons among the } \\
\text { students }\end{array}$ & 687 & 2.83 & .962 \\
\hline 9 & $\begin{array}{l}\text { There is problem of disrespecting lecturers among the } \\
\text { students }\end{array}$ & 687 & 3.00 & .528 \\
\hline 10 & There is problem of truancy among the students & 687 & 3.09 & .291 \\
\hline
\end{tabular}

Source: Field Data (2018)

Table 4.2 reveals that majority of the respondents agreed that students of tertiary educational institutions of Sokoto state portray different forms of indiscipline behaviours such as drug abuse $(\mathrm{M}=3.05 ; \mathrm{SD}=.481)$, examination malpractices $(\mathrm{M}=3.42 ; \mathrm{SD}=.494)$, fighting $(\mathrm{M}=$ 2.84; $\mathrm{SD}=.526)$, noise making in the Lecture Rooms $(\mathrm{M}=3.18 ; \mathrm{SD}=.581)$, stealing $(\mathrm{M}=2.72$; $\mathrm{SD}=.449)$, indecent dressing $(\mathrm{M}=3.24 ; \mathrm{SD}=.603)$, adultery and fornications $(\mathrm{M}=2.86 ; \mathrm{SD}=$ $.345)$, possession of illegal weapons $(M=2.83 ; \mathrm{SD}=.962)$, disrespecting the lecturers $(\mathrm{M}=3.00$; $\mathrm{SD}=.528)$ and truancy $(\mathrm{M}=3.09 ; \mathrm{SD}=.291)$. Similarly, in the interview conducted with the participants on the forms of indiscipline behaviours of the students of tertiary educational institutions, it was gathered that, the students of the institutions exhibit behaviours like disrespecting the lecturers (A1, A4, A3), drug abuse (A6, A2, A1, A3), examination malpractices (A6, A9), fighting (A1, A10, A12), noise making in the classrooms (A1, A4, A3, A2), stealing (A5, A9, A11), indecent dressing (A1, 12,), adultery and fornications (A2, A8), owning illegal weapons (A7, A8), and truancy (A9, A1, A5, and A7). 
Research Question Two: what are the causes of indiscipline among the students of tertiary educational institutions of Sokoto state?

Respondents opinions with regards to this research question are sown in table 2 as follows:

Table 2: Causes of students' indiscipline

\begin{tabular}{llccc}
\hline SN & \multicolumn{1}{c}{ Descriptor items } & N & Mean & SD \\
\hline 1 & Poor parenting style & 687 & 3.07 & .791 \\
\hline 2 & Mixed nature of the institution & 687 & 2.79 & .593 \\
\hline 3 & Overcrowded lecture rooms & 687 & 2.79 & .406 \\
\hline 4 & Peer group influence & 687 & 3.16 & .681 \\
\hline 5 & Ineffective disciplinary approaches in the institution & 687 & 2.90 & .802 \\
\hline 6 & Lack of guidance and counseling services & 687 & 1.91 & .570 \\
\hline 7 & Autocratic leadership of the institution & 687 & 2.00 & .581 \\
\hline 8 & Poor relationship between staff and students & 687 & 1.92 & .345 \\
\hline 9 & Indiscipline nature of some staff or lecturers & 687 & 2.91 & .291 \\
\hline
\end{tabular}

Source: Field Data (2018)

Table 4.3 displays that student's indiscipline in tertiary educational institutions of Sokoto State is a product of different causes such as poor parenting $(\mathrm{M}=3.07$; $\mathrm{SD}=.791)$, mixed nature of the institutions $(\mathrm{M}=2.79 ; \mathrm{SD}=.593)$, overcrowded Lecture rooms $(\mathrm{M}=2.79 ; \mathrm{SD}=.406)$, peer group influence $(\mathrm{m}=3.16$; $\mathrm{SD}=.681)$, ineffective discipline approaches $(\mathrm{M}=2.90 ; \mathrm{SD}=$ $.802)$ and indiscipline nature of some staff in the institutions $(\mathrm{M}=2.91$; $\mathrm{SD}=.291)$. This is understood from the mean scores of majorities of the respondents shown in the table above. On the other hand, the interview conducted with the participants, informed that the causes of students' indiscipline in the institutions under the study are no other than the overcrowded classrooms (A6, A9), peer group influence (A1, 12), poor parental upbringing (A1, A10, A12), lack of guidance and counseling (A1, A10, A12), combined sexes of the institutions (A1, A4, A3, A2), environmental influence (A6, A2, A1, A3), poor attitude of some staff (A9, A1, A5, and A7) and ineffective strategies of some institutions (A1, A4, A3).

Research Question Four: what are the Approaches for managing students' indiscipline in the tertiary educational institutions of Sokoto State?

This research question was answered and presented in table 3 below: 
Table 3: Approaches for managing students' indiscipline

\begin{tabular}{|c|c|c|c|c|}
\hline $\mathrm{SN}$ & Descriptor items & $\mathrm{N}$ & Mean & SD \\
\hline 1 & $\begin{array}{l}\text { The institution sets down strategic disciplinary rules and } \\
\text { regulations in the institution. }\end{array}$ & 687 & 3.33 & .635 \\
\hline 2 & $\begin{array}{l}\text { The institution communicates the rules to the school-wide } \\
\text { community. }\end{array}$ & 687 & 2.74 & .615 \\
\hline 3 & $\begin{array}{l}\text { The institution rewards students of good characters in the } \\
\text { institution }\end{array}$ & 687 & 1.92 & .345 \\
\hline 4 & $\begin{array}{l}\text { The institution inculcates moral habits among the misbehaving } \\
\text { students }\end{array}$ & 687 & 3.05 & .568 \\
\hline 5 & The institution apprehends and detains the indiscipline students & 687 & 2.60 & .651 \\
\hline 6 & $\begin{array}{l}\text { The institution suspends or expels the erring students if the need } \\
\text { be. }\end{array}$ & 687 & 2.95 & .713 \\
\hline 7 & $\begin{array}{l}\text { The institution uses difficult examinations to deal with the } \\
\text { indiscipline students }\end{array}$ & 687 & 2.00 & .581 \\
\hline 8 & $\begin{array}{l}\text { Lecturers send out misbehaving students from the classroom } \\
\text { during lectures }\end{array}$ & 687 & 2.79 & .590 \\
\hline 9 & $\begin{array}{l}\text { The institution provides guidance and counseling services to } \\
\text { misbehaving studs }\end{array}$ & 687 & 2.65 & .644 \\
\hline
\end{tabular}

Source: Field Data (2018)

Table 4.5 reveals that the tertiary educational institutions of Sokoto State employ certain strategies in managing students' disciplinary problems. The mean scores of the majority of the respondents agreed that the institutions set down strategic disciplinary rules and regulations in the institution $(\mathrm{M}=3.33$; $\mathrm{SD}=.635)$, communicate the rules to the schools-wide communities $(\mathrm{M}=2.74 ; \mathrm{SD}=.615)$, inculcate moral habits among the misbehaving students $(\mathrm{M}=3.05 ; \mathrm{SD}=$ $.568)$, apprehends and detains the indiscipline students $(\mathrm{M}=2.60 ; \mathrm{SD}=.651)$, suspends or expels the erring students if the need be $(\mathrm{M}=2.95 ; \mathrm{SD}=.713)$, lecturers send out misbehaving students from the classroom during the lectures $(\mathrm{M}=2.79 ; \mathrm{SD}=.590)$ and also provides guidance and counseling services to misbehaving students $(\mathrm{M}=2.65$; $\mathrm{SD}=.644)$. Furthermore, the participants interviewed on strategies for managing students' disciplinary problems in the tertiary educational institutions of Sokoto state, related that lecturers send out misbehaving students from the classroom during the lectures (A3, A1, A5, A6), the institutions suspend the indiscipline students whenever the need arises (A9, A11, A2), the institutions provide guidance and counseling services to the misbehaving students (A12, A4, A11, and A8), the institutions inculcate moral habits among the misbehaving studentsthrough weekly religious programs, etc. (A10, A8, A9, A7, and A11), the institutions set down strategic disciplinary rules and regulations (A3, A6, and $\mathrm{A} 9)$ and communicates them to the students, parents and the entire school community through notice boards, handbooks, orientations etc. (A1 and A8). 


\section{Discussion of the findings}

The study investigated the forms, causes and management approaches of students' indiscipline in the tertiary institutions of Sokoto State. Based on the findings, the forms of indiscipline actsthe students exhibit in the institutions include drug abuse, examination malpractice, fighting, noise making in the classrooms, stealing, indecent dressing, adultery and fornications, disrespecting the lecturers, possession of illegal weapons and truancy. These findings corroborate with the findings of other researchers such as Olaitan, et al, (2013), Petersen and Rosser (2008), Zubaida (2009) and Aneibonam, (2011) who contended that these actswere the most dangerous and most common students' disciplinary problems in Nigerian educational institutions. Ofcourse there is not contention whatsoever to see that the indiscipline attitudes of tertiary school students coincided with those of secondary schools' students and other tertiary institutions in the country because the higher institutions of learning are just extension of secondary schools. So, by implication the students tend to carry their secondary school behaviours to the tertiary schools; that was why secondary school remains the middle belt of education between the primary and tertiary ones.

On the causes of students' indiscipline, the study found that the main causes of indiscipline among the students of the tertiary institutions were poor parenting style and lack of parental counseling, mixed nature of the institutions, overcrowded classrooms, peer group influence, in effective school discipline strategies, and indiscipline nature of some staff in the institutions. These issues had already been identified by Ofori, et al. (2018), Bashar (2017), Balenakorodawa (2009), Lyamba (2013), Olaitan et al. (2013), Ifeoma (2012), Ojedapo and Idu (2011), Mtsweni (2008), Martha, Enose, and Serem (2013) who conducted different studies on diverse areas of students' indiscipline in different countries like Tanzania, Kenya, Ghana, South Africa, Nigeria, Malaysia and Ireland.The tandamness of these findings could not be marvelous due to the common nature and characteristics of the African nations and others in the Asian region of the globe.

Furthermore, the findings of the study showed that the approaches for managing the students' indiscipline in the institutions, were setting down strategic disciplinary rules and regulations inthe institutions, communicating the rules to the schools-wide communities, inculcating moral habits among the misbehaving students, apprehending and detaining the indiscipline students, expelling the erring students if the need arises, sending out the misbehaving students from the lecture rooms, and providing guidance and counseling services to the misbehaving students. These findings corroborated with the opinion of Bear, (2010) whosubmitted that a good school sets rules which act as a code of conduct for students to conform. The finding also goes in line with that of Aneibonam (2011) who identified inculcation of morality as one of the good measures of managing disciplinary problems in the Nigerian secondary schools. However, apprehendingand detaining the indiscipline students has been identified by Mugabe and Maposa (2013), Bell (1995), Olaitan et al. (2013), Aneibonam (2011), as one of the right approaches of enhancing the school discipline. Similarly, suspending the erring studentswas in line with what Aneibonam (2011) and Mugabe and Maposa (2013) postulated as a good method for managing students' discipline which school managers ought to always employ in dealing with the disruptive behaviors of indiscipline students. Moreover, sending out the misbehaving students from the classrooms during the lectures was one of the 
methods the stakeholders use to discipline the erring students in the institutions (Aneibonam, 2011). The finding also concurred with that of Mugabe and Maposa (2013) who reported that schools in Zimbabwe use counseling and disciplinary committees to manage the disciplinary problems of their students.

\section{Conclusion}

It is worth concluding that indiscipline behaviours were evident in the tertiary educational institutions of Sokoto State and those behaviours did not just happenedcoincidentally. The factors responsible for the students' indiscipline include among otherspoor parenting style and lack of parental counseling, mixed nature of the institutions, overcrowded classrooms, peer group influence, and indiscipline nature of some staff. The institutions adopted certain management strategies to curb the menace such as setting down strategic disciplinary rules and regulations in the institutions, communicating the rules to the schools-wide communities, inculcating moral habits among the misbehaving students, apprehending and detaining the indiscipline students, expelling the erring students from the institutions, sending out the misbehaving students from the lecture rooms, and providing guidance and counseling services. In order to improve the discipline of the students and the institutions in general, the paper put forward recommendations.

\section{Recommendations}

Going by the findings of the study, it is hereby recommended that:

i. The institutions should seek the support of the parents of the students and the entire community members in dealing with the indiscipline behaviours of the students.

ii. The institutions need to be organizing adequate sensitization programmes in their respective environments and other media houses like Radio and Television stations to make students aware of the penalties of the indiscipline behaviours they engage-in so that they may refrain.

iii. The institutions need to be awarding the discipline students with a reward for exhibiting moral conducts in the schools.

iv. The institutions need to be subjecting the indiscipline students with difficult examinations.

v. The institutions need to engage the supports of the religious and traditional rulers in dealing with the indiscipline students. 


\section{References}

Airat, S. (2014). Quantitative Research Methods. An unpublished manuscript, Department of Education foundations Faculty of Education, Islamic University in Uganda.

Alidzulwi, T. A. (2000). The role of parents in values education with special references to the situation in Venda (Northern Province).M.Ed Dissertation. Stellenbosch: University of Stellenbosch.

Amin, E.M. (2005). Social Science research: Conception, Methodology and Analysis. Kampala: Makerere University printer.

Aniebonam, U.F. (2011). Perceived Effectiveness of Management Techniques used by Secondary School Principals in Handling Students' Indiscipline. Ph. D Thesis: Nnamdi Azikwe University, Awka, Nigeria.

Azizi Y. et al (2009). Discipline Problems among Secondary School Students in Johor Bahru, Malaysia. European Journal of Social Sciences, 11(4), 22-37.

Baleinakorodawa, L. (2009). Causes of Truancy from Mainstream Education for a Group of Pasifika Students enrolled in Alternative Education. Masters' Dissertation: Auckland University of Technology.

Bashar, S. I. (2017). Inclusive ways of Managing Students' Discipline in Secondary Schools. Lambert Academic Publishing. ISBN 978-620-2-01043-6. www.morebooks.de/store/gb/book/inclusive-ways-of-manag

Bear, G.G. (2010). Discipline: Effective School Practices. University of Delaware.

Bell, E. B. (1995). Bullies and victims in schools. Milton Keynes: Open University Press.5

Bowman, D. H. (2004). Report notes on the impact of student behaviour. Education Week, 23(37), 33-41.

Creswell, J. W., \& Creswell, J. D. (2018). Research Design: Qualitative, Quantitative and Mixed Methods Approaches (5th ed.; H. Salmon, C. Neve, M. O'Heffernan, D. C. Felts, \& A. Marks, Eds.). USA: Los Angeles: SAGE

Dreikurs, R. (2015). The Social Discipline Model of Rudolf-Dreikurs. http://www.metu.edu.tr

Harris, A. (2002). The New School Leader for the 21st Century. Oxford: Scarecrow Press.

Hartup, E. (1983). Perceptions of discipline and ensuing discipline problems in secondary education. The South African Journal of Education, 20(1), 34-41.

Ifeoma, A.R. (2012). Indiscipline in Nigerian Secondary Schools: types, causes and possible solutions. African Journal of Education and Technology, 2 (1), 39-47. 
Igwe, S. O. (2000). Professional handbook for Teachers. Owerri: Milestone Imo State. Publishers Limited.

Karanjal, R. \& Bowen, M. (2012). Student Indiscipline and Academic Performance in Public Schools in Kenya. CRP Working Paper Number DU/2012/002, Daystar University.

Kreijcie, R.V, \&Morgan, D.W. (1970). Determining sample size for research activities. Educational and Psychological Measurement, 30, 607-610.

Lyamba, B. (2013). The relationship between Home environment and indiscipline among pupils in selected primary schools in Mongu district. Masters' Dissertation, University of Zambia, Lusaka.

Martha A. O., Enose, M. W. S. \&Serem, T. D. K. (2013).Management of pupil discipline in Kenya: A Case Study of Kisumu Municipality. International Research Journal of Educational Research. 4(5), 374-386.

Mtsweni, J. (2008). The Role of Education in the Management of School Discipline in the Nkangala Region of Mpumalanga. Master's Dissertation, University of South Africa, Cafe town.

Mucmahron, S. (2009). Wild pupils Trouble School. The Herald Sun, September.

Mugabe, M.J. \& Maposa, A.D. (2013). Methods of curbing learner misconduct in Zimbabwean secondary schools. International Journal of education, 4 (4), 10-19

Musisi, B. (2014). Managing discipline. Faculty of Education, Islamic University in Uganda.

Nakpodia, E.D. (2010). Teachers' disciplinary approaches to students' discipline problems in Nigerian secondary schools. International NGO Journal, 5(6), 144-15.

Ofori, K. N., Tordzro, G., Asamoah, E., and Achiaa, E. (2018). The effects of indiscipline on academic performance of Junior high school students in the Fantekwa District of Ghana. Journal of Education and Practice, 9(21), 109-117.

Ojedapo, D.O \& Idu, A.P (2011). Indiscipline in Secondary Schools: A cry to allstakeholders in Education. Journal of Education and Social Science Research, 1(5), 22-34.

Olaitan T., Mohammed, A.N., \& Ajibola, A.L. (2013). Management of Disciplinary Problems in Secondary Schools: Jalingo Metropolis in Focus. Global Journal of Human Social Science Linguistics \& Education. 13 (14),21-33.

Petersen, K. and R. Rosser (2008). Alternatives to corporal punishment. Sandown: Heinemann Publishers.

Rossouw, J. P. (2003). Learner discipline in South Africa public schools. Koers.

Stones, C. (2013). Indiscipline in American Schools: A coping strategy. Journal of Education and Technological Advancement. 2(9), 30-45. 
Sule, M. (2014). Prevalence of indiscipline traits among the contemporary Youths.Journal of Research and Practice, 2(1), 67-76.

Terry, B. W. (2001). Conducting Educational Research. Florida: Harcourt Brace \& Company.

Zubaida, A.N. (2009). Indiscipline and its Management Techniques: A case study of a special education school in Kano State. Journal of the National Council for exceptional children,11(2),455-463. 